\section{Unsafe abortion: social determinants and health inequities in a vulnerable population in São Paulo, Brazil}

\author{
Aborto inseguro: determinantes sociais e \\ iniquidades em saúde em uma população \\ vulnerável, São Paulo, Brasil
}

\author{
1 Universidade Federal de \\ São Paulo, São Paulo, Brasil. \\ 2 Associação para Pesquisa \\ e Promoção da Saúde e \\ dos Direitos da Mulher- \\ Gesto\&Ação, São Paulo, \\ Brasil. \\ Correspondence \\ C. L. B. Fusco \\ Departamento de Medicina \\ Preventiva, Universidade \\ Federal de São Paulo. \\ Rua Ceará 101, apto. 111, \\ São Paulo, SP \\ 01243-010, Brasil. \\ carmenlbf@uol.com.br
}

\begin{abstract}
This cross-sectional population-based study in a peripheral low-income community in São Paulo, Brazil, aimed to estimate the prevalence of unsafe abortion and identify the socio-demographic characteristics associated with it and its morbidity. The article discusses the study's results, based on univariate and multiple multinomial logistic regression analyses. The final regression models included: age at first intercourse $<16$ years $(O R=$ 4.80); $>2$ sex partners in the previous year $(O R=$ 3.63); more live born children than the woman's self-reported ideal number $(O R=3.09)$; acceptance of the abortion due to insufficient economic conditions $(O R=4.07)$; black ethnicity/color $(O R=2.67) ;$ and low schooling $(O R=2.46)$, all with $p<0.05$. The discussion used an approach to social determinants of health based on the concept and model adopted by the WHO and the health inequities caused by such determinants in the occurrence of unsafe abortion. According to the findings, unsafe abortion and socio-demographic characteristics are influenced by the social determinants of health described in the study, generating various levels of health inequities in this low-income population.
\end{abstract}

Abortion; Social Inequity; Social Medicine; Epidemiologic Factors
Carmen L. B. Fusco 1,2

Rebeca de Souza e Silva 1

Solange Andreoni 1

\section{Introduction}

"Unsafe abortion is defined as a procedure for terminating an unintended pregnancy either by people lacking the necessary professional skills or in an environment lacking the minimal medical standards, or both" 1.

The World Health Organization (WHO) estimates that 19 to 22 million abortions occur per year in the world under inadequate conditions (21.7 million in 2008 and 19.7 in 2003), at a constant rate of 14 unsafe abortions/1,000 women. Unless the access to safe abortion and effective contraceptives is ensured, the number of unsafe abortions is expected to grow, due to the increase in the number of childbearing-age women 1. From $20 \%$ to $50 \%$ of women who submit to abortions require medical care due to complications 2 . Unsafe abortion is thus a serious health hazard.

Worldwide, abortions performed in inadequate or at risk, i.e., in unsafe conditions, cause some 50 thousand deaths per year ( $13 \%$ of all maternal deaths) 1 . Deaths caused by abortion are preventable 3.

The global unsafe abortion case-fatality rate is $220 / 100$ thousand abortions 1 , that is, $0.22 \%$, meaning that at least two maternal deaths are expected for every one thousand procedures. Even with the decrease in the incidence of post-abortion complications and thus in the number of maternal deaths due to abortion in recent years 4,5 , the unsafe abortion case-fatality rate is 350 times 
higher than the safe abortion case-fatality rate in the United States, for the latter is negligible 1. The aggregate case-fatality rate due to complications of legal abortion in 13 countries, mostly developed nations, for which exact data are available is 0.6 deaths per 100 thousand abortions 6 . The case-fatality and mortality rates in these countries are low, mainly because abortions are performed by skilled professionals using appropriate equipment and in aseptic conditions.

According to the Pan American Health Organization (PAHO), unsafe abortion is the leading cause of maternal mortality in Latin America and the Caribbean 7 . This region as a whole, with an annual average of 4,230,000 unsafe abortions, also presents the highest clandestine/unsafe abortion rate, namely 31/1,000 childbearing-age women 1.

Among the causes of maternal mortality in Brazil, unsafe abortion currently ranks fourth. However, it may also be included among the two causes immediately ahead of it - hemorrhagic syndromes and postpartum infections -, which would actually make it the third leading cause of maternal death, since abortion is rarely reported on death certificates. In 2003, the maternal mortality ratio obtained from reported deaths was 51.7 maternal deaths per 100 thousand live births, and the official corrected maternal mortality ratio was 72.4 per 100 thousand live births, corresponding to 1,572 maternal deaths 8 . Since abortion is classified as a crime under Brazil's Criminal Code, and due to deficiencies in the reporting system for maternal deaths, there is enormous underreporting of such deaths, even though maternal death has been subject to compulsory notification since 20038,9 .

Nearly all abortions under inadequate or unsafe conditions occur in developing or poor countries, where abortion is limited by law. In $2003,97 \%$ of all unsafe abortions occurred in developing countries like Brazil 6, whose Criminal Code, dating to 1940 10, allows abortion in only two cases: (i) if there is no other way to save the pregnant woman's life or (ii) if the pregnancy resulted from rape. This legal provision, out of step with reality, leads to a "condition of clandestineness" in which the vast majority of abortions take place clandestinely, thus, in unsafe conditions 9 .

Unsafe abortion is also a serious public health problem in Brazil 11. Considering only the hospitalization data from the Unified National Health System (SUS), the total number of unsafe abortions per year in Brazil ranges from 750 thousand to 1.5 million; estimates for the year 2005 point to $1,054,242$ abortions, a figure below the actual number, due to underreporting 12,13.
Deaths due to abortion in Brazil occur mostly in poor, young, black women with poor schooling, thus denoting a high rate of social injustice and health inequity 12,14 . Studies on clandestine abortion in contexts in which abortion is heavily restricted by law indicate that women with higher income have greater probability of submitting to induced abortion under safe conditions, as compared to lower income women 15.

In view of the problem's magnitude, where only the tip of the iceberg is known, it is crucial to study the determinants of this event and the conditions in which it takes place 16 . The determinants of unsafe abortion include legal restrictions on abortion, poor social support, inadequate family planning services, and the deficient health services infrastructure 3 , besides other social determinants.

Social determinants of health are defined as the social, economic, cultural, ethnic/racial, psychological, and behavioral factors that influence the occurrence of health problems and their risk factors in the population, generating health inequalities and/or inequities 17 . Social determinants of health play an important role in the outcome of unintended or unplanned pregnancies; women in disadvantaged social circumstances are more likely to experience an unintended pregnancy than those with better financial and social resources 15 .

Meanwhile, health inequalities can be defined as differences in a health condition or in the distribution of its determinants between different population groups or subgroups. When such inequalities generate inequity, one refers to health inequities. The principal determinants of these inequities relate to the forms by which social life is organized 18. Health inequities and inequities in access to health services between groups and individuals should be considered avoidable, unjust, and unnecessary 19 .

Developing countries are more likely to restrict access to legal abortion than developed countries, and such restriction affects poorer women disproportionately, generating health inequities 15.

Brazil lacks empirical epidemiological data on unsafe abortion 11 in vulnerable populations with very low income, in which abortion carries greater weight in the maternal morbidity and mortality rates and where there is an even clearer need to deal with the issue of preventive family planning as one of the main reproductive health-related issues. Further research is also needed to identify which social determinants of health make these populations more vulnerable specifically to unsafe abortion and to women's health problems in general. Thus, the current 
study aimed to estimate the prevalence of unsafe abortion and to identify the socio-demographic characteristics associated with it and its morbidity, using an approach based on the social determinants of abortion and health inequities in a poor population.

\section{Material and methods}

A cross-sectional survey was carried out with all women 15-54 years of age living in a favela (slum) on the North Side of São Paulo city in the second semester of 2005 and first semester of 2006. Of the 382 women living in that community and belonging to the age bracket, 375 were interviewed, while only 7 (1.8\%) refused to participate in the study.

Data collection used a direct structured interview applied by trained interviewers in the women's homes. The data collection instrument includes three elements grouped together: family composition (with household monthly per capita income); a structured, pre-coded questionnaire for collecting socio-demographic data; and a history of pregnancies, with an annex on abortionrelated complications and hospitalizations.

The interviews were conducted by three monitors from the community and three Human Sciences university students who were previously trained in workshops before holding the interviews in home visits to the local women at an appropriate time for the interviewees. This procedure was previously tested in a pilot group and the supervision was performed by the fieldwork coordinator throughout the data collection process. The women were encouraged to participate in the study, and absolute confidentiality of the information was assured, including not requiring identification of the interviewees 9 .

The dependent variable abortion was divided into 3 categories: no abortion or only live births (NA/LB); spontaneous abortion (SA); and induced abortion (IA). The independent variables were: age at first intercourse; marital status at time of first event; ethnicity/color; State origin or internal migration (native of São Paulo State versus from other States of Brazil); religion; paid work/activity; per capita income (divided into 2 categories with the mean as the cutoff); schooling (low, or up to 4 years of schooling, and not low, more than 4 years of schooling); self-reported number of sexual partners in the year prior to the study; contraceptive use in the pregnancy related to the event; mismatch, or the difference between the number of live born children and the self-reported ideal number of children (LB - IN), with the following categories: fewer, when the number of live born children was less than the number of children reported as ideal $(\mathrm{LB}<$ IN); same, when the values for the two variables were identical $(\mathrm{LB}=\mathrm{IN})$; more, when the woman had more live born children as compared to what she reported as ideal ( $\mathrm{LB}>\mathrm{IN}$ ).

In addition to these variables, the study investigated the level of acceptance of the abortion, including the following situations: lack of acceptance of the abortion, or in the case of acceptance, the reasons, namely fetal malformation, risk to the woman's life, woman's health problems, rape, insufficient economic conditions, family already complete, single marital status, living alone, and not wanting to have children.

The data were analyzed in two groups: one with all the women that were interviewed, and the other including only the women with a history of pregnancy, thus excluding the 97 women who had never been pregnant.

First, the prevalence of abortion (induced and spontaneous) was calculated among women 1554 years of age living in the community. The data analysis used tests of association (chi-square or Fisher's exact test), Kruskal-Wallis test (for per capita income), and univariate and multiple multinomial logistic regression models, with the NA/LB variable as the reference category. Variables that showed associations with $\mathrm{p}<0.20$ were selected to enter an initial multiple multinomial logistic regression model using the backward stepwise method 20, 21. In all the analyses, statistical significance was set at $p<0.05$. Statistical analysis of the data used SPSS 16.0 for Windows (SPSS Inc., Chicago, USA).

Both stages of the study were approved by the Institutional Review Board of the Federal University in São Paulo (Universidade Federal de São Paulo - UNIFESP, no. 1300/06 and no. 0990/10). The study applied for and was granted exemption from the requirement of signing a free informed consent form due to the nature of the study.

\section{Results}

A high number of abortions was detected in this study-144 abortions in the sample of 375 women, of whom 93 had suffered or induced an abortion, corresponding to a prevalence rate of $24.8 \%$. The mean in this group of 93 women was 1.55 abortions per woman. Of the 144 abortions, 82 were reported as induced (IA), in 51 women (prevalence $=13.6 \%$ ) and 62 as spontaneous (SA), in 42 women (prevalence $=11.2 \%$ ). Analyzing only the group of women with a history of pregnancy, the proportions were: IA = 51/278 (18.34\%) and SA = $42 / 278$ (15.1\%). 
The induced abortions were all clandestine and unsafe, having been induced either in locations with unhygienic or non-aseptic conditions, without professional follow-up of any kind, or by individuals without even a minimum professional training, in inadequate locations, such as the interviewee's own home ( $\mathrm{sic}$ ) or others 1 . Of the 82 induced abortions, only 4 had been performed in clandestine clinics specifically named by the interviewees, without any professional qualifications 1 .

Many abortions declared as spontaneous (miscarriages) may actually have been induced. However, for purposes of methodological rigor, this study only considered unsafe abortions those declared as induced (IA $=\mathrm{UA}$ ).

Approximately $70 \%$ of the women who underwent unsafe abortions had not used contraceptive at the time of the pregnancy. The mean age of the women in all abortions (SA and IA) was 23.1 years. Mean age at the first induced abortion was lower, 21.6 years, and these women were younger on average at their first pregnancy (17.2 years). More than $50 \%$ of the women had their first intercourse between 11 and 16 years of age; the figure was $52 \%$ for women with a history of abortion (SA or IA). Only 33.3\% of the women had their first induced abortion in their first pregnancy, while $66.6 \%$ had their induced abortions in subsequent pregnancies.

Income was measured as the current monthly per capita household income. Mean per capita income (for women that reported their income) was distributed as follows: per capita income of women with no abortion $=$ BR $\$ 241.00$; per capita income of women with SA = R\$232.10; per capita income of women with induced abortion $=\mathrm{R} \$$ 173.60 (< 1/2 the monthly minimum wage).

Per capita income was significantly lower in the induced abortion group ( $p=0.017$ ), with a mean of less than one-half the minimum wage.

The study also showed a high morbidity rate involving complications related to unsafe abortion, especially hemorrhage and infections (94.12\%), leading to $83.3 \%$ of admissions to hospitals in the public healthcare system ${ }^{9}$.

Tables 1 and 2 show the results of the univariate analyses. For the total sample of women, the characteristics that were significantly associated with IA were: single marital status; black ethnicity/color; low schooling; per capita monthly income less than BR\$200.00; Evangelical religion (protective factor); age less than 16 years at first intercourse; 2 or more sex partners in the year prior to the study; having more children (live born) than the self-reported ideal number; and all the situations investigated in relation to acceptance of the abortion, except for risk to the woman's life and woman's health problems. Factors significantly associated with SA were internal migration (from another State of Brazil to São Paulo), low schooling, and having more children than the self-reported ideal number. When analyzing only the sample of women with a history of pregnancy, factors significantly associated with IA were: single marital status; black ethnicity/ color; low schooling; per capita monthly income less than BR \$200.00; age at first intercourse $<16$ years; 2 or more sex partners in the year prior to the study; and acceptance of the abortion due to insufficient economic conditions, family already complete, single marital status, mother living alone, and mother not wanting more children. No factors were significantly associated with SA (Tables 1 and 2).

Tables 3 and 4 show the multiple multinomial logistic regression models. After stepwise removal of the variables that lost significance, 6 variables remained that were statistically significant for the total group of women, of which 5 remained in the group of women with a history of pregnancy (Tables 3 and 4). For IA/UA, factors that remained in the final model for the total group of women (Table 3 ) were: age at first intercourse $<16$ years $(\mathrm{OR}=4.80 ; \mathrm{p}<0.001) ; 2$ or more sex partners in the previous year $(\mathrm{OR}=3.63$; $\mathrm{p}=0.020)$; number of live born children > ideal $(\mathrm{OR}=3.09$; $\mathrm{p}=$ 0.008); acceptance of the abortion due to insufficient economic conditions $(\mathrm{OR}=4.07 ; \mathrm{p}=0.001)$; black ethnicity/color $(\mathrm{OR}=2.67$; $\mathrm{p}=0.011)$; and low schooling $(\mathrm{OR}=2.46 ; \mathrm{p}=0.028)$. For $\mathrm{SA}$, the only variable that remained was migration, that is, the fact that women came from outside the State of São Paulo (OR = 3.2; $\mathrm{p}=0.007$ ). In the final model for women that reported a history of pregnancy (Table 4), for IA/UA the following variables remained: age at first intercourse $<16$ years; 2 or more sex partners in the previous year; acceptance of the abortion due to insufficient economic conditions; black ethnicity/color; and low schooling. Marital status at the time of the first event showed borderline significance, but was left in the model because of its importance in the specialized literature. None of the variables was significantly associated with SA.

To help investigate the social determinants of unsafe abortion and health inequities, we chose to analyze the epidemiological interaction between ethnicity/color and the variables schooling, marital status, and income (Table 5). The analysis showed a strong statistical association between these interactions and IA/UA. Considering ethnicity/color and schooling, the highest proportion of induced abortions (35.7\%) occurred among black women with incomplete primary schooling. Similar proportions were seen 
Univariate analysis of variables (socio-demographic characteristics) associated with induced abortion (IA) and spontaneous abortion (SA) in the total sample of women.

\begin{tabular}{|c|c|c|c|}
\hline \multirow[t]{2}{*}{ Variable } & \multirow[t]{2}{*}{ Categories $(1) /(0)$} & IA & \multirow{2}{*}{$\begin{array}{c}\text { SA } \\
\text { OR (p-value) }\end{array}$} \\
\hline & & OR (p-value) & \\
\hline Marital status at first event & Unmarried/Married & $2.188(0.044)$ & $0.625(0.163)$ \\
\hline Religion & Evangelical/Not Evangelical & $0.453(0.025)$ & $0.661(0.243)$ \\
\hline Paid activity/work & No/Yes & $1.040(0.897)$ & $0.826(0.565)$ \\
\hline Age at 1 st intercourse & Age $<16 / \geq 16$ years & $4.253(<0.001)$ & $1.554(0.200)$ \\
\hline Number of partners (previous year) & $\geq 2 /<2$ & $3.093(0.015)$ & $1.279(0.706)$ \\
\hline Contraceptive use related to 1 st event & No/Yes & $0.739(0.368)$ & $1.478(0.341)$ \\
\hline Mismatch & $\begin{array}{c}\text { Number of live born children } \geq \text { ideal } /< \\
\text { ideal }\end{array}$ & $4.567(<0.001)$ & $2.261(0.018)$ \\
\hline \multirow{10}{*}{$\begin{array}{l}\text { Considers induced abortion acceptable in these } \\
\text { situations }\end{array}$} & Yes/No & & \\
\hline & Fetal malformation & $2.376(0.021)$ & $0.554(0.076)$ \\
\hline & Woman's life at risk & $1.874(0.069)$ & $0.819(0.549)$ \\
\hline & Woman's health problems & $1.625(0.125)$ & $0.772(0.438)$ \\
\hline & Rape & $2.388(0.033)$ & $0.424(0.010)$ \\
\hline & Insufficient economic conditions & $4.945(<0.001)$ & $0.785(0.702)$ \\
\hline & Family already complete & $4.216(<0.001)$ & $1.000(1.000)$ \\
\hline & Single marital status & $3.732(0.002)$ & $0.728(0.678)$ \\
\hline & Living alone & $4.455(<0.001)$ & $0.687(0.622)$ \\
\hline & Does not want to have children & $4.231(0.001)$ & $0.825(0.802)$ \\
\hline Ethnicity/Color & Black/Not black & $3.211(0.001)$ & $0.868(0.780)$ \\
\hline Schooling & Low $(<4$ years)/Not low ( $>4$ years) & $3.344(0.001)$ & $2.295(0.019)$ \\
\hline Migration & From outside São Paulo/From São Paulo & $1.154(0.643)$ & $3.433(0.003)$ \\
\hline Monthly per capita income & $\leq \mathrm{BR} \$ 200 />\mathrm{BR} \$ 200$ & $3.419(0.001)$ & $0.833(0.586)$ \\
\hline
\end{tabular}

Reference category: no abortion.

in single black women (36.7\%) and black women with low income, or less than BR\$200.00 (40.0\%). The lowest proportions of induced abortions were verified in non-black women with at least complete primary schooling $(6.7 \%)$, non-black women who were married or in stable unions $(8.7 \%)$, and non-black women with monthly income greater than BR\$ 200.00 (6.7\%) (Table 5).

\section{Discussion}

This study focused on women living in a lowincome community in the city of São Paulo and specifically aimed to analyze the influence of social determinants of health on the occurrence of abortion and the associated socio-demographic characteristics, and the health inequities caused by these determinants, with unsafe abortion as the principal health outcome, with its consequences and/or complications. Importantly, un- safe abortion is not an issue of "free choice", but the consequence of social determinants and different health opportunities between individuals and groups 15.

For analysis of the main fieldwork results, the reference adopted here was the concept proposed and used by the WHO International Commission on Social Determinants of Health, focused on health interventions 22 .

In Brazil, persons in situations of vulnerability and social risk who belong to families with a per capita income of up to one-half the minimum wage are classified by the Ministry of Social Development as affected by poverty and social exclusion. They belong to "populations in situations of poverty and/or indigence" and are the principal victims of social inequality 23 .

Societies with steeper income inequality gradients, such as Brazil, present more social and health problems as compared to more egalitarian countries 24 . Rich and poor differ in more than 
Univariate analysis of variables (socio-demographic characteristics) associated with induced abortion (IA) and spontaneous abortion (SA) for the sample of women with history of pregnancy.

\begin{tabular}{|c|c|c|c|}
\hline \multirow[t]{2}{*}{ Variable } & \multirow[t]{2}{*}{ Category (1) } & IA & \multirow{2}{*}{$\begin{array}{c}\text { SA } \\
\text { OR ( } p \text {-value) }\end{array}$} \\
\hline & & OR (p-value) & \\
\hline Marital status at 1 st event & Unmarried & $3.635(0.001)$ & $1.038(0.913)$ \\
\hline Religion & Evangelical & $0.555(0.106)$ & $0.808(0.562)$ \\
\hline Paid activity/work & No & $1.098(0.768)$ & $0.872(0.690$ \\
\hline Age at 1 st intercourse & $<16$ years & $3.688(<0.001)$ & $1.347(0.401)$ \\
\hline Number of partners (previous year) & $\geq 2$ & $4.116(0.007)$ & $1.702(0.447)$ \\
\hline Contraceptive use related to 1 st event & No & $0.739(0.368)$ & $1.478(0.341)$ \\
\hline Mismatch & Number of live born children $\geq$ ideal & $1.878(0.092)$ & $0.930(0.838)$ \\
\hline \multirow[t]{10}{*}{ Considers induced abortion acceptable in these situations } & Yes & & \\
\hline & Fetal malformation & $2.080(0.058)$ & $0.485(0.036)$ \\
\hline & Risk to mother's life & $1.662(0.156)$ & $0.726(0.355)$ \\
\hline & Mother's health problems & $1.545(0.185)$ & $0.734(0.370)$ \\
\hline & Rape & $2.073(0.082)$ & $0.368(0.004)$ \\
\hline & Insufficient economic conditions & $3.570(0.001)$ & $0.566(0.375)$ \\
\hline & Family already complete & $3.654(0.002)$ & $0.867(0.828)$ \\
\hline & Single & $3.373(0.008)$ & $0.658(0.591)$ \\
\hline & Living alone & $3.938(0.002)$ & $0.607(0.520)$ \\
\hline & Doesn't want children & $3.373(0.008)$ & $0.658(0.591)$ \\
\hline Ethnicity/Color & Black & $2.583(0.008)$ & $0.698(0.487)$ \\
\hline Schooling & Low & $2.266(0.024)$ & $1.555(0.227)$ \\
\hline Migration & From outside São Paulo State & $0.703(0.227)$ & $2.091(0.081)$ \\
\hline Monthly per capita income & $<\mathrm{BR} \$ 200$ & $2.509(0.014)$ & $0.611(0.157)$ \\
\hline
\end{tabular}

Reference category: no abortion.

Table 3

Multiple analysis of variables (socio-demographic characteristics) associated with induced abortion (IA) and spontaneous abortion (SA) in the total sample of women.

\begin{tabular}{|c|c|c|c|}
\hline \multirow[t]{2}{*}{ Variable } & \multirow[t]{2}{*}{ Categories $(1) /(0)$} & IA & \multirow{2}{*}{$\begin{array}{c}\text { SA } \\
\text { OR (p-value) }\end{array}$} \\
\hline & & OR (p-value) & \\
\hline Age at 1 st intercourse & $<16$ years $/ \geq 16$ years & $4.801(<0.001)$ & $1.758(0.120)$ \\
\hline Number of partners (previous year) & $\geq 2 /<2$ & $3.637(0.020)$ & $1.545(0.524)$ \\
\hline Mismatch & Number of live born children $\geq$ ideal/< ideal & $3.089(0.008)$ & $1.633(0.196)$ \\
\hline Accepts abortion/insufficient economic conditions & Yes/No & $4.069(0.001)$ & $0.730(0.628)$ \\
\hline Ethnicity/Color & Black/Not black & $2.679(0.011)$ & $0.796(0.661)$ \\
\hline Schooling & Low $(<4$ years)/Not low (> 4 years) & $2.459(0.028)$ & $1.639(0.203)$ \\
\hline \multirow[t]{2}{*}{ Migration } & From outside São Paulo State/From São & $1.291(0.492)$ & $3.191(0.007)$ \\
\hline & Paulo & & \\
\hline
\end{tabular}

Reference category: no abortion.

income, since the latter, among others, is also responsible for health. The vast disparity between rich and poor is a growing threat to health, as reflected in the morbidity and mortality gradients both within and between countries 22 . The problem of income inequality and/or social stratification, structural determinants of health, causes individuals to occupy different social positions, 
Multiple analysis of variables (socio-demographic characteristics) associated with induced abortion (IA) and spontaneous abortion (SA) for the sample of women with history of pregnancy.

\begin{tabular}{lccc}
\hline Variable & Category (1) & $\begin{array}{c}\text { IA } \\
\text { SA } \\
\text { OR (p-value) }\end{array}$ & (p-value) \\
\hline Age at 1st intercourse & & $3.911(<0.001)$ & $1.384(0.383)$ \\
Number of partners (previous year) & $<16$ years & $3.307(0.041)$ & $1.778(0.419)$ \\
Accepts abortion/ insufficient economic conditions & Yes & $3.355(0.005)$ & $0.575(0.393)$ \\
Ethnicity/Color & Black & $2.270(0.039)$ & $0.671(0.446$ \\
Schooling & Low & $2.858(0.010)$ & $1.683(0.163)$ \\
Marital status at first event & Unmarried & $2.199(0.067)$ & $0.985(0.967)$ \\
\hline
\end{tabular}

Reference category: no abortion.

\begin{tabular}{|c|c|c|c|c|}
\hline & \multicolumn{4}{|c|}{ Abortion -3 categories } \\
\hline & None & SA & IA/UA & Total \\
\hline & n (\%) & $n(\%)$ & n (\%) & $n(\%)$ \\
\hline \multicolumn{5}{|l|}{ Ethnicity/color and schooling } \\
\hline Not black and complete primary schooling or greater & $129(86.0)$ & $11(7.3)$ & $10(6.7)$ & $150(100.0)$ \\
\hline Not black and incomplete primary schooling & $115(69.7)$ & $26(15.8)$ & $24(14.5)$ & $165(100.0)$ \\
\hline Black and complete primary schooling or greater & $14(77.8)$ & $2(11.1)$ & $2(11.1)$ & $18(100.0)$ \\
\hline Black and incomplete primary schooling & $24(57.1)$ & $3(7.1)$ & $15(35.7)$ & $42(100.0)$ \\
\hline Total & $282(75.2)$ & $42(11.2)$ & $51(13.6)$ & $375(100.0)$ \\
\hline \multicolumn{5}{|l|}{ Ethnicity/color and marital status } \\
\hline Not black and married or in stable union & $137(74.9)$ & $30(16.4)$ & $16(8.7)$ & $183(100.0)$ \\
\hline Not black and single & $107(81.1)$ & $7(5.3)$ & $18(13.6)$ & $132(100.0)$ \\
\hline Black and married or in stable union & $19(63.3)$ & $5(16.7)$ & $6(20.0)$ & $30(100.0)$ \\
\hline Black and single & $19(63.3)$ & $0(0.0)$ & $11(36.7)$ & $30(100.0)$ \\
\hline Total & $282(75.2)$ & $42(11.2)$ & $51(13.6)$ & $375(100.0)$ \\
\hline \multicolumn{5}{|l|}{ Ethnicity/color and monthly per capita income } \\
\hline Not black and > BR\$200.00 & $120(80.0)$ & $20(13.3)$ & $10(6.7)$ & $150(100.0)$ \\
\hline Not black and $<$ BR $\$ 200.00$ & $119(75.3)$ & $16(10.1)$ & $23(14.6)$ & $158(100.0)$ \\
\hline Black and > BR $\$ 200.00$ & $15(83.3)$ & $2(11.1)$ & $1(5.6)$ & $18(100.0)$ \\
\hline Black and $<$ BR $\$ 200.00$ & $21(52.5)$ & $3(7.5)$ & $16(40.0)$ & $40(100.0)$ \\
\hline Total & $275(75.1)$ & $41(11.2)$ & $50(13.7)$ & $366(100.0)$ \\
\hline
\end{tabular}

$p<0.001$ for the 3 analyses.

generating inequities 22 , and reaching its maximum expression in terms of health in poor populations, such as slum-dwellers. Such populations, like the one in the current study, compared to the average population in the city to which they belong (São Paulo), clearly show the abovementioned gap or disparity, especially regarding morbidity. Thus the study population's per capita income and the income discrepancy between the group of women with induced and unsafe abortion (per capita income $<1 / 2$ minimum wage) and the two other groups of women, with SA and without abortion, is fully explained as part in the determination of the entire process of this popu- 
lation's greater vulnerability to unsafe abortion ${ }^{9}$. Unsafe induced abortion in poor women involves health inequities due to the higher number of abortions, the inadequate conditions in which they occur, and the higher resulting morbidity, also leading to a higher mortality rate (difficult to measure). Meanwhile, women with better financial resources that submit to induced abortion, even though illegal or partially illegal, are able to do so without this abortion becoming unsafe, even though it is clandestine 15 . Numerous studies have shown higher complication and mortality rates resulting from unsafe abortion among women with low socioeconomic status 15 .

The acceptance of induced abortion as conditioned by economic or financial factors, lack of material conditions to have and raise a child (despite the resistance to accepting the abortion itself), denotes the gravity of income disparity in the study population.

In a sense, schooling represents income when the latter cannot be measured, and thus its dual importance. Countries with greater income inequality also perform worse in the level of schooling, and even more so in the lower economic strata 24.

The complex relationship between education and other demographic characteristics, fertility preferences, contraception, and abortion is reflected in the very different patterns found in the few studies in which this information (educational or schooling level) is available 25 . As an example of the indirect role of education in pregnancy and abortion, contraceptive use is closely related to the women's level of schooling. Better educated women have more knowledge of contraceptive methods and their use and can choose the more effective methods as compared to their less educated peers $26,27,28$. Studies such as those conducted in Brazil by Brazilian Society for Family Welfare (Bem-Estar Familiar no Brasil BEMFAM) with data from the National Demographic and Health Survey, 1996, show an inverse relationship between degree of schooling and teenage pregnancy ${ }^{29}$. Meanwhile, the teenage pregnancy rate is strongly associated with relative poverty and inequality and thus also with low schooling 24 . This is confirmed in the current study population, in which the mean age of women at the time of their induced abortions for the first pregnancy was 17.2 years, all with low schooling (fewer than 4 years of schooling) 9 .

The vulnerability to unintended pregnancy is strongly influenced by access and use, or non-use, of effective contraception, in addition to exposure to undesired sex, early marriage, and sexual violence, factors correlated with low schooling 15 . Women in situations of economic/financial dis- advantage and low schooling, producing inequities, show a higher probability of reporting lack of knowledge on sexual and reproductive health, including family planning, besides limited access to contraceptives and increased rates of adverse health effects as reasons for lack of contraceptive use. Women with more schooling not only acquire more knowledge, but also have greater autonomy and capacity to choose 15 .

In this study, the great majority of the women that underwent induced abortions, especially those with less schooling, reported not using contraceptives at the time of their pregnancy (70\%), thus exposing themselves to risk of unintended pregnancy and therefore induced abortion. This also explains the higher odds of unsafe abortion in women with less schooling.

As compared to this study's results, some studies 13,30 have shown divergent findings for the association between low schooling and IA/ UA; however they were conducted among women with different socioeconomic status and/or regional conditions.

Age at first intercourse is a good predictor of initial exposure to a pregnancy 31 which in turn is a necessary condition for the occurrence of abortion. More than $50 \%$ of the young women in the study population reported sexual initiation between 11 and 16 years of age and practically no preventive measures against a possible pregnancy ${ }^{9}$. Differential vulnerability to unintended pregnancy is much greater in this age bracket, especially among women with low income and poor schooling, either due to lack of the necessary knowledge or experience, or to erratic sexual activity, lack of communication with sex partners, and lack of control over life circumstances 15.

The number of sex partners during the year prior to the study probably reflects more systematic pregnancy-prone behavior, besides denoting lack of adherence to contraceptive use, which leads consequently to induced abortion 15 . In the WHO model, such behaviors are on the threshold between individual factors and social determinants of health, since behaviors, which are often interpreted as merely involving individual responsibility, depending on persons' free will choices, in reality can also be considered part of the social determinants of health, since such choices are heavily conditioned by social determinants 22 .

In this study population, there was a high proportion of women with at least as many live born children as compared to what they reported as the ideal number 30 , with an increased probability of continuing to submit to unsafe abortions, which is also not due to free choice, but rather demonstrates the use of abortion to con- 
trol fertility, within the specific context and given the social determinants acting on it. In 2002, the fertility rate in São Paulo was 1.88 children per woman, lower than the replacement level 32 , demonstrating a social stimulus for the drop in fertility.

Marital status is also entangled in this threshold between individual factors and social determinants of health. This socio-demographic characteristic is one of the possible factors in the occurrence, or lack thereof, of an induced abortion in the presence of an unplanned pregnancy. The distribution of abortions by marital status varies according to the scientific literature, and particularly according to the specific region 25 . In the United States and Cuba, countries with distinct socioeconomic, political, and cultural realities (including religion), induced abortion is more frequent among single women, as in Brazil in poor communities. Single women in the United States have a fourfold probability of submitting to induced abortion, as compared to married women 25 . In this study sample, the women's marital status varied greatly over the course of their childbearing history, between single, "cohabiting", and married, but unsafe abortion was associated with "living alone" at the time of this event.

According to an international review on induced abortion, including countries in which abortion is legal and others whether it is restricted by law, developed and developing countries, published in 1999, the authors concluded: "In more than half of the countries studied, married women obtain a larger proportion of abortions than unmarried women. However, once pregnant, unmarried women are more likely than married women to choose abortion" 25 (p. 68).

Like schooling, ethnicity/color was also associated with income in the study population. According to Buss 33 , color is a proxy for social situation in Brazil, with the presence of health inequities belonging to this context. As is known, "With regard to health status, differences between blacks and whites were striking” 34 (p. 305).

In 2000, according to census data, blacks represented $45 \%$ of the total Brazilian population. However, blacks are $63 \%$ of the poor population, and among the poor, the majority are women 35 .

Black (African-descendant) women in Brazil have less access to education, worse living and housing conditions, less access to contraceptive methods, and higher odds of becoming pregnant (although not always intentionally) 36. Thus, the North, Northeast, and Central-West of Brazil concentrate the majority of deaths of black women due to problems in the pregnancy cycle (pregnancy, delivery, and postpartum), includ- ing abortion, as well as the majority of maternal deaths 37 .

According to the WHO model as the reference for action on social and macrosocial determinants of health 22, ethnicity/color is permeated both by other structural determinants of health (such as income, education, and gender) and by intermediate determinants defined by socioeconomic status (housing, work, psychological, and behavioral conditions, etc.), which in turn generate exposures that are potentially harmful to health and increase the underlying vulnerability of susceptible populations. The structural and intermediate determinants influence each other in a feedback loop, leading to health inequities, which in the case of the black population result from all the possible interactions between the diverse determinants 22 .

The findings obtained in the favela (slum) setting, analyzed here in relation to ethnicity/ color, are consistent with the literature and with social and macrosocial determinants of health 22 , culture 38 , and the history of the black population in Brazil. The women that submitted to unsafe abortion included a higher proportion of black, low-income, and single women with less than 4 years of schooling as compared to white women, which alone demonstrates the presence of health inequities.

Of the black (African-descendant) women, a large proportion consists of migrants from other States (not São Paulo), especially from the Northeast region of Brazil 9. The majority of the migrant population consists of young, African-descendant, unmarried women with low schooling and high poverty and high unemployment rates 39 . In this study, migrant women showed higher odds of suffering spontaneous abortion. This finding merits more in-depth investigation. Accumulated health problems? A response bias?

Finally, in this study population the morbidity rate was much higher than that reported in higher income women's populations or those with access to safe abortion 5,15 . The great majority of women that submitted to unsafe abortions reported complications, especially hemorrhage, with a high proven number of hospitalizations, mostly in public hospitals in the area. As mentioned previously, mortality from abortion is difficult to measure, so that morbidity, a predisposing condition, constitute the principal characteristic representing health inequities in this context.

In conclusion, unsafe abortion and the main socio-demographic characteristics associated therewith are influenced by the social determinants of health described above, generating various levels of health inequities among women with a history of abortion. 
Women in this poor population, who would benefit directly from the legalization of abortion, deserve to be included in an effective family planning program, or at least in a harm reduction program, while awaiting modification of the prevailing law.

\section{Resumo}

Valendo-se de uma pesquisa de base populacional, com desenho transversal, realizada em uma comunidade da periferia de São Paulo, Brasil, que teve como objetivos estimar a prevalência de mulheres com aborto inseguro, identificar as características sociodemográficas a ele associadas, e sua morbidade, são discutidos neste artigo os resultados, após efetuadas análises de regressão logística multinomial univariadas e múltipla. Tem-se nos modelos finais da regressão: idade da 1a relação sexual < $16(\mathrm{OR}=4,80)$; número de parceiros no último ano $>2(\mathrm{OR}=3,63)$; número de filhos nascidos vivos $>$ ideal $(O R=3,09)$; aceitação do aborto por falta de condições econômicas $(\mathrm{OR}=4,07)$; etnia negra/cor preta $(O R=2,67)$; e escolaridade baixa $(O R=2,46)$, todos com $p<0,05$. Foi utilizada na discussão uma abordagem voltada aos determinantes sociais da saúde, segundo conceito e modelo adotados pela WHO, e às iniquidades em saúde por esses geradas na ocorrência do aborto inseguro. Verificou-se que o aborto inseguro e características sociodemográficas são influenciados pelos determinantes sociais da saúde descritos, gerando nessa população iniquidades em saúde de proporções diversas.

Aborto; Iniquidade Social; Medicina Social; Fatores Epidemiológicos

\section{Contributors}

C. L. B. Fusco was responsible for the data collection and conceptualization, writing, and critical review of the article. R. S. Silva collaborated in the study design, data analysis, and revision of the article. S. Andreoni collaborated in the data analysis and revision of the article.

\section{References}

1. World Health Organization. Unsafe abortion: global and regional estimates of the incidence of unsafe abortion and associated mortality in 2008. 6th Ed. http://whqlibdoc.who.int/publica tions/2011/9789241501118_eng.pdf (accessed on 02/Aug/2011).

2. Grimes DA. Unsafe abortion: the silent scourge. $\mathrm{Br}$ Med Bull 2003; 67:99-113.

3. Fawcus S. Maternal mortality and unsafe abortion. Best Pract Res Clin Obstet Gynaecol 2008; 22: 533-48.

4. Silva DF, Bedone AJ, Faúndes A, Fernandes AM, Lima e Moura VG. Aborto provocado: redução da frequência e gravidade das complicações. Consequência do uso de misoprostol? Rev Bras Saúde Matern Infant 2010; 10:441-7.

5. Singh S, Monteiro MF, Levin J. Trends in hospitalization for abortion complications and the potential impact of misoprostol use: the case of Brazil. In: Seminar on The Health, Social and Economic Consequences of Unsafe Abortion. San Juan del Río: IUSSP Scientific Panel on Abortion and Population Council's Mexico Office; 2010. p. 1-30.

6. Sedgh G, Henshaw S, Singh S, Ahman E, Shah IH. Induced abortion: estimated rates and trends worldwide. Lancet 2007; 370:1338-45.

7. Pan American Health Organization. Equidad de género y salud en las Américas a comienzos del siglo XXI. Washington DC: Pan American Health Organization; 2004.

8. Departamento de Ações Programáticas Estratégicas, Secretaria de Atenção à Saúde, Ministério da Saúde. Manual dos comitês de mortalidade materna. 3a Ed. Brasília: Ministério da Saúde; 2007 (Série A. Normas e Manuais Técnicos).

9. Fusco CLB, Andreoni S, Silva RS. Epidemiologia do aborto inseguro em uma população em situação de pobreza Favela Inajar de Souza, São Paulo. Rev Bras Epidemiol 2008; 11:78-88.

10. Código Penal e Constituição Federal. 14a Ed. São Paulo: Editora Saraiva; 2008. 
11. Diniz D. Aborto e saúde pública no Brasil [Editorial]. Cad Saúde Pública 2007; 23:1992-3.

12. Adesse L, Monteiro MF, Levin J. Panorama do aborto no Brasil: grave problema de saúde pública e de justiça social. Radis: Comunicação em Saúde 2008; 66:10-5.

13. Departamento de Ciência e Tecnologia, Secretaria de Ciência, Tecnologia e Insumos Estratégicos, Ministério da Saúde. Aborto e saúde pública no Brasil: 20 anos. Brasília: Ministério da Saúde; 2009 (Série B. Textos Básicos de Saúde).

14. Rede Feminista de Saúde. Dossiê aborto: mortes preveníveis e evitáveis. Belo Horizonte: Rede Feminista de Saúde; 2005.

15. Malarcher S, Olson LG, Hearst N. Unintended pregnancy and pregnancy outcome: equity and social determinants. In: Blas E, Kurup AS, editors. Equity, social determinants and public health programmes. Geneva: World Health Organization; 2010. p. 177-97.

16. Martins IR, Costa SH, Freitas SRS, Pinto CS. Aborto induzido em mulheres de baixa renda: dimensão de um problema. Cad Saúde Pública 1991; 7:251-66.

17. Buss PM, Pellegrini Filho A. A saúde e seus determinantes sociais. Physis (Rio J.) 2007; 17:77-93.

18. Magalhães R. Monitoramento das desigualdades sociais em saúde: significados e potencialidades das fontes de informação. Ciênc Saúde Coletiva 2007; 12:667-73.

19. Whitehead M. The health divide. In: Townsend P, Whitehead M, Davidson N, editors. Inequalities in health: the Black report and the health divide. London: Penguin; 1992. p. 214-450.

20. Kleinbaum DG, Mitchel K. Logistic regression: a self-learning text. 2nd Ed. New York: Springer-Verlag; 2002.

21. Massad E, Menezes RX, Silveira PS, Ortega NR. Métodos quantitativos em medicina. São Paulo: Manole; 2004.

22. Semenza JC, Maty SC. Acting upon the macrosocial environment to improve health: a framework for intervention. In: Galea S, editor. Macrosocial determinants of population health. New York: Springer Science Business Media; 2007. p. 443-61.

23. Assis SG. Desigualdade e exclusão, atalhos para a violência. Rio de Janeiro: Empresa Municipal de Multimeios, Prefeitura do Rio de Janeiro; 1995. http:// www.multirio.rj.gov.br/seculo21/texto_ link.asp?cod_link $=95 \&$ cod_chave $=2 \& l e t r a=c \quad(a c-$ cessed on 13/Jul/2006).

24. Wilkinson R, Pickett K. The spirit level. New York: Bloomsbury Press; 2009.

25. Bankole A, Singh S, Haas T. Characteristics of women who obtain induced abortion: a worldwide review. Int Fam Plan Perspect 1999; 25:68-77.

26. Berquó E, Morell MGG, Silva RS, Marques RM. São Paulo e sua fecundidade: um estudo das variáveis intermediárias e dos diferenciais sócio-econômicos da fecundidade. v. 1. São Paulo: Fundação Sistema Estadual de Análise de Dados; 1985.
27. Fundação Sistema Estadual de Análise de Dados. A fecundidade da mulher paulista. São Paulo: Fundação Sistema Estadual de Análise de Dados; 1994. http://dtr2004.saude.gov.br/nutricao/bs_1/docu mentos/pnds_1996/00frontmatter.pdf (accessed on 06/Sep/2006).

28. McDevitt TM, Adlakha A, Fowler TB, Harris-Bourne $\mathrm{V}$. Trends in adolescent fertility and contraceptive use in the developing word. http://www.census. gov/ipc/prod/ipc95-1/ipc95_1.pdf (accessed on 06/Sep/2006).

29. Bem-Estar Familiar no Brasil. Pesquisa Nacional sobre Demografia e Saúde 1996. Rio de Janeiro: Bem-Estar Familiar no Brasil; 1997.

30. Silva RS. Padrões de aborto provocado na Grande São Paulo, Brasil. Rev Saúde Pública 1998 32:7-17.

31. Berquó E. Sobre o sistema internacional de pesquisas em demografia e saúde reprodutiva. Rev Bras Epidemiol 2008; 11 Suppl 1:S72-89.

32. Yazaki LM. Fecundidade da mulher paulista abaixo do nível de reposição. Estud Av 2003; 17:65-86.

33. Buss PM. Globalização, pobreza e saúde. Ciênc Saúde Coletiva 2007; 12:1575-89.

34. Barata RB, Almeida MF, Montero CV, Silva ZP. Health inequalities based on ethnicity in individuals aged 15 to 64, Brazil, 1998. Cad Saúde Pública 2007; 23:305-13.

35. Jaccoud LB, Beghin N. Desigualdades raciais no Brasil: um balanço da intervenção governamental. Brasília: Instituto de Pesquisa Econômica Aplicada; 2002.

36. Lopes F. Experiências desiguais ao nascer, viver, adoecer e morrer: tópicos em saúde da população negra no Brasil. In: Batista LE, Kalckmann S, organizadores. Seminário saúde da população negra Estado de São Paulo 2004. São Paulo: Instituto de Saúde; 2005. p. 53-101.

37. Laurenti R, Mello-Jorge MHP, Gotlieb SLD. Estudo da mortalidade de mulheres de 10 a 49 anos, com ênfase na mortalidade materna. Brasília: Ministério da Saúde; 2006.

38. Eckersley RM. Culture. In: Galea S, editor. Macrosocial determinants of population health. New York: Springer Science Business Media; 2007. p. 193-209.

39. Loue S, Galea S. Migration. In: Galea S, editor. Macrosocial determinants of population health. New York: Springer Science Business Media; 2007. p. 247-73.

Submitted on 01/May/2011

Final version resubmitted on 31/Oct/2011

Approved on 23/Nov/2011 